\title{
ENVIRONMENTAL AND BEHAVIOR FACTORS ON THE INCIDENCES OF TOXOPLASMOSIS AMONG MARRIED WOMEN
}

\author{
Andi Asnifatima1), Siti Khodijah Parinduri'1), Ahsin Aligori²) \\ 1) Study Program of Public Health, Faculty of Health Sciences, Universitas Ibn Khaldun, Bogor \\ 2) Philanthropic Institute, Dompet Dhuafa Republika
}

\begin{abstract}
Background: Toxoplasmosis is a condition in which a person is infected with Toxoplasma gondii. Humanitarian transmission is closely linked to the environment in which they live and the conduct that allows the entry into the body of Oocyst Toxoplasma gondii. Toxoplasmosis in married women is very dangerous because it can cause conditions of infertility, repeated spontaneous abortion, stillbirth, and congenital abnormalities. This study aimed to analyze the association between environmental and behavior on toxoplasmosis incidences among married women.

Subjects and Method: This was a case-control study carried out at the Alternative Medical Clinic, Aquatreat Therapy Indonesia Foundation in Bogor City during 2019. Total of 160 women were enrolled in this study and divided into 2 groups: 80 in case group and 80 in control group. The dependent variable was toxoplasmosis behavior. The independent variables were environmental and behavior factors. Data were collected from clinical laboratory results and questionnaire and analyzed using a multiple logistic regression.

Results: In environmental factors, presence of pets at home $(\mathrm{OR}=3.73 ; 95 \% \mathrm{CI}=1.83$ to 7.61 ; $\mathrm{p}<0.001)$, presence of wild cats or neighboring cats that are often seen around the house $(\mathrm{OR}=$ $2.63 ; 95 \% \mathrm{CI}=1.24$ to $5.58 ; \mathrm{p}=0.012)$, and risky environment $(\mathrm{OR}=9.60 ; 95 \% \mathrm{CI}=3.74$ to 24.61; p < 0.001) were significantly associated with toxoplasmosis among married women. In behavior factors, consumption of raw vegetables/vegetables $(\mathrm{OR}=4.53 ; 95 \% \mathrm{CI}=1.23$ to 16.73 ; $\mathrm{p}=0.023)$, consumption of smoked meat/ steak/ undercooked $(\mathrm{OR}=3.32 ; 95 \% \mathrm{CI}=0.12$ to 0.77 ; $\mathrm{p}<0.001)$, food buying habits at roadside stalls $(\mathrm{OR}=8.64 ; 95 \% \mathrm{CI}=0.03$ to $0.50 ; \mathrm{p}<0.001)$, and washing hands before eating $(\mathrm{OR}=0.29 ; 95 \% \mathrm{CI}=1.80$ to $25.50 ; \mathrm{p}=0.006)$ were significantly associated with toxoplasmosis among married women.
\end{abstract}

Conclusion: Environmental and behavior factors are positively associate with toxoplasmosis among married women.

Keywords: determinant, environment, behavior, toxoplasmosis, married woman

\section{Correspondence:}

Andi Asnifatima. Study Program of Public Health, Faculty of Health Sciences, Universitas Ibn Khaldun, Bogor, West Java. Email: asni@uika-bogor.ac.id. Hp: +6281355879086.

The $7^{\text {th }}$ International Conference on Public Health

Solo, Indonesia, November 18-19, 2020 | 205 https://doi.org/10.26911/the7thicph.03.25 